DOI: https://doi.org/10.24867/06GI05Sabo

\title{
КОМПАРАТИВНА АНАЛИЗА ИНВЕСТИЦИОНИХ ФОНДОВА У РЕПУБЛИЦИ СРБИЈИ
}

\section{ANALYSIS OF INVESTMENT FUNDS IN REPUBLIC OF SERBIA}

\author{
Ивана Сабо, Факултет техничких наука, Нови Сад
}

\begin{abstract}
Област - Индустријско инжењерство и менаџмент Кратак садржај - Рад се бави пословањем инвестициионх фондова у Републици Србији. У Србији, инвестициони фондови су регулисани Законом о инвестиционим фондовима из 2006. године, који је измењен и допуњен у пар наврата, 2009. године, 2011. године и 2014. године. Овај закон инвестиционе фондове дефинише као институцију колективног инвестирања у оквиру којег се прикупљају и улажу новчана средства у различите врсте имовине са ичием остварења прихода и смањења ризика улагања. У Србији су законом прописани отворени, затворени и приватни инвестициони фондови. Инвестициони фондови се према Закону о инвестиционим фондовима, региструју при Комисији за хартије од вредности која води Регистар инвестиционих фондова. У регистру је тренутно активно 20 инвестициионих фондова.
\end{abstract}

Кључне речи: Инвестициони фондови, повратак инвестиција, итедюа

Abstract Paper is focused on investment funds business in Republic of Serbia. The first part of the paper explains from a theoretical pointof view the concept and emergence of investment funds as well as the principles of their functioning. In the research part, investment funds operating on the market of Republic of Serbia are presented and comparative analysis of their operations in previous period is given. The final part of the paper gives a conclusion and directions for further research as well as a list of relevant literature that has been used

Key words: Investment funds, analysis of investment funds in Republic of Serbia, return of investment, saving

\section{1. РЕЗИМЕ}

Инвестициони фондови су најтипичнији представници институционалних инвеститора. Они су најпогоднија форма за мобилизацију новца и капитала од вишемилионских власника. До капитала долазе продајом својих удела или акција и добијена средства улажу у диверсификовани портфолио хартија од вредности. Инвестициони фондови обогаћују структуру финансијског посредовања, повећавају конкурентност, врше продубљивање тржишта капитала. У свим земљама са тржишном привредом инвестициони фондови имају кључну улогу у функционисању развоја тржишта капитала, као и остварењу његове стабилности. Они су доживели праву експанзију у високо развијеним земљама где

\section{НАПОМЕНА:}

Овај рад проистекао је из мастер рада чији ментор је био проф. др Ранко Бојанић. егзистирају снажни инвестициони фондови, прави финансијски дивови. У модификованој форми они су потврдили своју сврсисходност и у земљама у развоју. У Србији су се инвестициони фондови појавили 2007. године, и они инвеститорима нуде неколико предности: професионално управљање фондом, диверзификацију, једноставан приступ и ликвидност. Тренутно је у Србији активно 20 инвестиционих фондова од којих су 18 отворени, а 2 су приватна али у процецу гашења. Постоји 6 активних друштава за управљање, и 4 кастоди банке. Инвестициони фондови бележе значајан раст у претходних 5 година на нашем тржишту.

\section{1. Циљ и предмет истраживања}

Циљ истраживања је представљање значаја и потенцијала улагања у инвестиционе фондове у Републици Србији. Након свих турбуленција наше привреде у последњих 30 година, од ратних дешавања, економских санкција, дуготрајне и тешко спроведене транзиције која и даље није завршена за друштво као целину, пољуљано је поверење како грађана, тако и привреде у поузданост и резултат инструмената развоја као што су инвестициони фондови. Сматрам да овим истраживањем помажем подизању свести о значају улагања, предности које оваква врста улагања доноси, ризицима који прате улагање у инвестиционе фондове и утицају које улагање у инвестиционе фондове дугорочно може донети становништву Републике Србије. Као породична особа која је и запослена и која учествује у приватном породичном бизнису, овим истраживањем сам желела да укажем да улагањем у инвестиционе фондове, не само да увећавамо стечену вредност одређене индивидуе, него кроз едукацију укажем на доступност и понуду инвестиционих фондова у Републици Србији.

\section{2. ИНВЕСТИЦИОНИ ФОНД - ПОЈАМ И НАСТАНАК ИНВЕСТИЦИОНИХ ФОНДОВА У СРБИЈИ И СВЕТУ}

Инвестициони фонд представља институционални облик прикупљања новчаних средстава већег броја инвеститора ради колективног инвестирања прикупљених средстава у различите облике финансијске активе, са примарним циљем да се оствари принос за улагаче, уз смањени ризик кроз диверзификацију пласмана, с тим да инвестиционим фондом оперативно управља инвестициона компанија. Инвестиционе компаније односно друштва за управљање инвестиционим фондовима управљају са 
више инвестиционих фондова од којих сваки има своје циљеве, менаџмент, стратегију инвестирања и портфолио структуру. Инвестиционе компаније су као институција одвојене од инвестиционог фонда чије функционисање оперативно сервисирају. Целокупна имовина инвестиционог фонда је у власништву чланова инвестиционог фонда и подељена је на једнаке делова односно инвестиционе јединице. Ово значи да свака акција инвестиционе компаније представља сразмерно учешће у портфолију хартија од вредности под њеном управом. Управљање портфолиом инвестициона компанија спроводи у име и у најбоље, интересу њених акционара. Остварени приход на основу хартија од вредности дели се акционарима, сразмерно њиховом учешћу, умањени за износ вредности провизије на име портфолио менаџмент услуге. Основне предности инвестиционих фондова:

- Доступност и лакоћа куповине акција инвестиционим фондовима

- Аутоматско реинвестирање

- Аутоматско повлачење средстава

- Аутоматски инвестициони план

- Пензиони рачуни као саставни део понуде

- Омогућен приступ на међународно тржиште

- Висок степен ликвидности и могућности брзог повраћаја средстава

- Принципи пословања фондова су прецизно и јасно дефинисани.

\section{1.Основни ризици улагања у инвестиционе фондове}

- Накнаде - инвестори су обавезни за друштву за управљање плацају накнаде за управљање фондом без обзира који је његов уцинак, то знаци да се та вредност смањује уколико инвестициони фонд има губитак

- Недостатак контроле - инвеститори не знају у сваком моменту шта тачно садржи портфолио фонда и нису у могућности да утичу на инвестиционе одлуке које доноси друштво за управљање

Сви ризици се могу поделити у две групе и то:

1) Ризици на које друштво за управљање

инвестиционим фондовима може да утиче

2) Ризици на које друштво за управљање инвестиционим фондовима не може самостално да утиче

\section{2. Врсте инвестиционих фондова у Србији и свету}

У свету врсте инвестиционих фондова најчешће можемо поделити на:

- Отворени инвестициони фондови

- Затворени инвестициони фондови

- Интервални затворени инвестициони фондови (креирају се приликом преласка из затвореног у отворени фонд)

- Фондови некретнина

- Хеџ фондови

- Приватни фондови ${ }^{1}$

${ }^{1}$ Шошкић, Д., Живковић, Б.: „Финансијска тржишта и институције”, Центар за издавачку
У Србији, наш закон препознаје

- отворене,

- затворене и

- приватне инвестиционе фондове.

Отворене и затворене инвестиционе фондове регулише Закон о инвестиционим фондовима, а насупрот њих су приватни инвестициони фондови који су организовани као друштва са ограниченом одговорношћу и послују по одредбама Закона о привредним друштвима.

\section{3. Историјат инвестиционих фондова у Србији}

У Србији инвестициони фондови представљају релативно нову инвестициону могућност доступну последњих десетак година.До септембра 2008. је већина фондова бележила значајан раст, већи од било ког уобичајеног улагања, што је утицало на брз раст вредности фондова. Потом су се појавили први знаци кризе и њихов спорији развој.

Значајан потенцијал и могућност за зараду и развој инвестиционих фондова, међутим, и даље постоји, нарочито ако се има у виду да грађани на штедним рачунима у банкама имају 54,5 милијарди динара и 9,7 милијарди евра и да штедња у Србији има тренд раста.

У Србији у 2019. послује шест друштава за управљање инвестиционим фондовима, односно 20 отворених инвестиционих фондова који нуде различит очекивани принос, а који зависи од ризичности финансијских инструмената у које се улаже, а то је за сваки фонд унапред дефинисано и записано у проспекту.

Табела 1: Списак регистрованих друштава за управљане инвестиичоним фондовима

\begin{tabular}{|l|c|}
\hline \multicolumn{1}{|c|}{$\begin{array}{c}\text { Регистровани званични назив } \\
\text { друштва }\end{array}$} & $\begin{array}{c}\text { Датум добијања } \\
\text { дозволе за рад }\end{array}$ \\
\hline FIMA INVEST A.D. BEOGRAD & 21.03 .2007 \\
\hline ILIRIKA DZU A.D. BEOGRAD & 20.09 .2007 \\
\hline INTESA INVEST AD BEOGRAD & 02.02 .2018$. \\
\hline $\begin{array}{l}\text { KOMBANK INVEST A.D. } \\
\text { BEOGRAD }\end{array}$ & 31.01 .2008$. \\
\hline $\begin{array}{l}\text { RAIFFEISEN INVEST A.D. } \\
\text { BEOGRAD }\end{array}$ & 31.05 .2007 \\
\hline $\begin{array}{l}\text { WVP FUND MANAGEMENT } \\
\text { A.D. BEOGRAD }\end{array}$ & 07.07 .2017$. \\
\hline
\end{tabular}

\section{3.ПРИНЦИПИ ФУНКЦИОНИСАҢА ИНВЕСТИЦИОНИХ ФОНДОВА}

Да би на најбољи начин објаснили систем функционисања инвестиционих фондова у Републици Србији морамо утврдити основне појмове дефинисане Законом о инвестиционим фондовима:

1) друштво за управљање - привредно друштво чија је основна делатност управљање инвестиционим фондом, у складу са законом

2) инвестициони фонд - институција колективног инвестирања у оквиру које се прикупљају и улажу

делатност економског факултета у Београду, Београд, 2006., стр. 264. 
новчана средства у различите врсте имовине са циљем остварења прихода и смањења ризика улагања

3) кастоди банка - банка која води рачун инвестиционог фонда и обавља друге кастоди услуге за рачун инвестиционог фонда, а у погледу средстава инвестиционог фонда поступа само по налозима друштва за управљање који су у складу са законом и проспектом инвестиционог фонда

4) члан, односно акционар инвестиционог фонда физичко или правно лице на чије име су регистроване инвестиционе јединице, односно акције инвестиционог фонда

5) инвестициона јединица - сразмерни обрачунски удео у укупној нето имовини инвестиционог фонда

6) квалификовано учешће - посредно или непосредно учешће у друштву за управљање које представља најмање $10 \%$ капитала, односно гласачких права или које омогућава остварење значајног утицаја на управљање друштвом за управљање у којем постоји такво учешће. За утврђивање гласачких права у смислу ове одредбе примењују се одредбе о значајним учешћима закона којим се уређује тржиште капитала

7) проспект - основни документ инвестиционог фонда који потенцијалним инвеститорима пружа потпуне и јасне информације за доношење одлуке о улагању

7а) скраһени проспект - кратак документ који садржи кључне информације за инвеститоре и које су, као такве, јасно назначене у скраћеном проспекту. Кључне информације за инвеститоре морају садржати одговарајуће информације о најважнијим карактеристикама фонда, као што су врсте улагања и могући ризици, а које омогућавају инвеститорима да донесу утемељену одлуку о предложеном улагању

8) члан управе је директор или члан надзорног одбора у смислу закона којим се уређују привредна друштва

9) портфолио фонда чини имовина у коју инвестициони фонд улаже у складу са одредбама овог закона. ${ }^{2}$

\section{1. Накнаде и врсте трошкова инвестиционих} фондова

Свако друштво за управљање је дужно да има правилник о тарифи и да наплаћује накнаде и трошкове за сваки фонд којим управља у складу са њим и проспектом.

Друштво за управљање може наплаћивати накнаду за куповину и накнаду за откуп инвестиционих јединица од чланова отвореног фонда.

Из имовине отвореног фонда могу се наплаћивати:

1) накнада друштву за управљање за управљање имовином фонда

2) трошкови куповине и продаје хартија од вредности

3) трошкови кастоди банке

4) трошкови екстерне ревизије

5) други трошкови у складу са актом Комисије

Накнаде које се наплаћују од члана фонда:

\footnotetext{
23акон о инвестиционим фондовима, члан 2, 2006. година.
}

1. накнада за куповину инвестиционих јединица (,улазна накнада“ или “front-end loads”) - наплаћује се као проценат од улога инвеститора у фонд

2. накнада за откуп инвестиционих јединица ( „излазна накнада“, или ,back-end loads“) наплаћује се када члан фонда жели да повуче (,прода“) свој улог из фонда и да уновчи инвестиционе јединице које поседује. Код већине фондова је ова накнада 0, али код неких фондова се наплаћује.

\section{4. КОМПАРАТИВНА АНАЛИЗА ИНВЕСТИЦИОНИХ ФОНДОВА У РЕПУБЛИЦИ СРБИЈИ У 2019. ГОДИНИ}

Табела 2: Списак регистрованих инвестищионих фондова у Републици Србији у августу 2019

\begin{tabular}{|c|c|c|c|c|c|}
\hline Назив & Тип & Под тип & $\begin{array}{l}\text { Друштво за } \\
\text { управљање }\end{array}$ & $\begin{array}{l}\text { Датум } \\
\text { уписа у } \\
\text { региста }\end{array}$ & $\begin{array}{l}\text { Кастоди } \\
\text { банка }\end{array}$ \\
\hline $\begin{array}{l}\text { RAIFFEISEN } \\
\text { EURO CASH }\end{array}$ & отворен & $\begin{array}{c}\text { фонд } \\
\text { очувања } \\
\text { вредности } \\
\text { имовине } \\
\end{array}$ & $\begin{array}{l}\text { RAIFFEISEN } \\
\text { INVEST A.D. } \\
\text { BEOGRAD }\end{array}$ & $\begin{array}{l}13.11 .2 \\
012 .\end{array}$ & $\begin{array}{c}\text { UNICREDIT } \\
\text { BANK SRBIJA } \\
\text { A.D. } \\
\text { BEOGRAD } \\
\end{array}$ \\
\hline $\begin{array}{c}\text { FIMA } \\
\text { PROACTIVE }\end{array}$ & отворен & $\begin{array}{c}\text { фонд } \\
\text { раста } \\
\text { вредност }\end{array}$ & $\begin{array}{l}\text { FIMA INVEST A.D. } \\
\text { BEOGRAD }\end{array}$ & $\begin{array}{c}04.05 .2 \\
007 .\end{array}$ & $\begin{array}{c}\text { KOMERCIJALN } \\
\text { A BANKA A.D. } \\
\text { BEOGRAD }\end{array}$ \\
\hline $\begin{array}{c}\text { ILIRIKA } \\
\text { BALANCED }\end{array}$ & отворен & \begin{tabular}{|c|}
$\begin{array}{c}\text { балансирани } \\
\text { фонд }\end{array}$ \\
\end{tabular} & $\begin{array}{l}\text { ILIRIKA DZU A.D. } \\
\text { BEOGRAD }\end{array}$ & $\begin{array}{c}26.03 .2 \\
009 .\end{array}$ & $\begin{array}{c}\text { VOJVOĐANSK } \\
\text { A BANKA A.D. } \\
\text { NOV } S A D \\
\end{array}$ \\
\hline $\begin{array}{c}\text { INTESA } \\
\text { INVEST } \\
\text { COMFORT } \\
\text { EURO } \\
\end{array}$ & отворен & $\begin{array}{c}\text { балансирани } \\
\text { фонд }\end{array}$ & $\begin{array}{l}\text { INTESA INVEST } \\
\text { AD BEOGRAD }\end{array}$ & $\begin{array}{c}10.08 .2 \\
018 .\end{array}$ & $\begin{array}{c}\text { ERSTE BANK } \\
\text { A.D. NOVI } \\
\text { SAD }\end{array}$ \\
\hline $\begin{array}{c}\text { WVP } \\
\text { BALANCED }\end{array}$ & отворен & $\begin{array}{c}\text { балансирани } \\
\text { фонд }\end{array}$ & $\begin{array}{l}\text { WVP FUND } \\
\text { MANAGEMENT } \\
\text { A.D. BEOGRAD }\end{array}$ & $\begin{array}{l}19.10 .2 \\
017 .\end{array}$ & $\begin{array}{c}\text { VOJVOĐANSK } \\
\text { A BANKA A.D. } \\
\text { NOVI SAD }\end{array}$ \\
\hline $\begin{array}{l}\text { KOMBANK } \\
\text { IN FOND }\end{array}$ & отворен & $\begin{array}{c}\text { балансирани } \\
\text { фонд }\end{array}$ & $\begin{array}{l}\text { KOMBANK } \\
\text { INVEST A.D. } \\
\text { REOGRAD }\end{array}$ & $\begin{array}{c}27.05 .2 \\
008 .\end{array}$ & $\begin{array}{c}\text { VOJVOĐANSK } \\
\text { A BANKA A.D. } \\
\text { NOVI } S A D\end{array}$ \\
\hline $\begin{array}{l}\text { RAIFFEISEN } \\
\text { WORLD }\end{array}$ & отворен & $\begin{array}{c}\text { балансирани } \\
\text { фонд }\end{array}$ & $\begin{array}{l}\text { RAIFFEISEN } \\
\text { INVEST A.D. } \\
\text { BEOGRAD }\end{array}$ & $\begin{array}{l}05.08 .2 \\
010 .\end{array}$ & $\begin{array}{c}\text { UNICREDIT } \\
\text { BANK SRBIJA } \\
\triangle \square \\
\end{array}$ \\
\hline $\begin{array}{c}\text { ILIRIKA } \\
\text { CASH EURO }\end{array}$ & отворен & $\begin{array}{c}\text { фонд } \\
\text { очувања } \\
\text { вредности } \\
\text { имовине } \\
\end{array}$ & $\begin{array}{l}\text { ILIRIKA DZU A.D. } \\
\text { BEOGRAD }\end{array}$ & $\begin{array}{c}07.04 .2 \\
011 .\end{array}$ & $\begin{array}{c}\text { VOJVOĐANSK } \\
\text { A BANKA A.D. } \\
\text { NOVI SAD }\end{array}$ \\
\hline $\begin{array}{l}\text { RAIFFEISEN } \\
\text { CASH }\end{array}$ & отворен & $\begin{array}{c}\text { фонд } \\
\text { очувања } \\
\text { вредности } \\
\text { имовине } \\
\end{array}$ & $\begin{array}{l}\text { RAIFFEISEN } \\
\text { INVEST A.D. } \\
\text { BEOGRAD }\end{array}$ & $\begin{array}{c}04.03 .2 \\
010 .\end{array}$ & $\begin{array}{c}\text { UNICREDIT } \\
\text { BANK SRBIJA } \\
\text { A.D. } \\
\text { BEOGRAD }\end{array}$ \\
\hline $\begin{array}{l}\text { ILIRIKA } \\
\text { CASH } \\
\text { DINAR }\end{array}$ & отворен & $\begin{array}{c}\text { фонд } \\
\text { очувања } \\
\text { вредности } \\
\text { имовине } \\
\end{array}$ & $\begin{array}{l}\text { ILIRIKA DZU A.D. } \\
\text { BEOGRAD }\end{array}$ & $\begin{array}{l}20.11 .2 \\
009 .\end{array}$ & $\begin{array}{c}\text { VOJVOĐANSK } \\
\text { A BANKA A.D. } \\
\text { NOVI SAD }\end{array}$ \\
\hline $\begin{array}{c}\text { INTESA } \\
\text { INVEST } \\
\text { CASH } \\
\text { DINAR }\end{array}$ & отворен & $\begin{array}{c}\text { фонд } \\
\text { очувања } \\
\text { вредности } \\
\text { имовине } \\
\end{array}$ & $\begin{array}{l}\text { INTESA INVEST } \\
\text { AD BEOGRAD }\end{array}$ & $\begin{array}{l}05.10 .2 \\
018 .\end{array}$ & $\begin{array}{l}\text { ERSTE BANK } \\
\text { A.D. NOVI } \\
\text { SAD }\end{array}$ \\
\hline $\begin{array}{l}\text { KOMBANK } \\
\text { DEVIZNI } \\
\text { FOND }\end{array}$ & отворен & $\begin{array}{c}\text { фонд } \\
\text { очувања } \\
\text { вредности }\end{array}$ & $\begin{array}{c}\text { KOMBANK } \\
\text { INVEST A.D. } \\
\text { BEOGRAD }\end{array}$ & $\begin{array}{l}12.12 .2 \\
014 .\end{array}$ & $\begin{array}{c}\text { VOJVOĐANSK } \\
\text { A BANKA A.D. } \\
\text { NOVI SAD }\end{array}$ \\
\hline $\begin{array}{c}\text { KOMBANK } \\
\text { NOVČANI } \\
\text { FOND }\end{array}$ & отворен & $\begin{array}{c}\text { фонд } \\
\text { очувања } \\
\text { вредности } \\
\end{array}$ & $\begin{array}{c}\text { KOMBANK } \\
\text { INVEST A.D. } \\
\text { BEOGRAD } \\
\end{array}$ & $\begin{array}{l}05.07 .2 \\
013 .\end{array}$ & $\begin{array}{c}\text { VOJVOĐANSK } \\
\text { A BANKA A.D. } \\
\text { NOVI SAD } \\
\end{array}$ \\
\hline WVP CASH & отворен & $\begin{array}{c}\text { фонд } \\
\text { очувања } \\
\text { вредности } \\
\text { имовине } \\
\end{array}$ & $\begin{array}{l}\text { WVP FUND } \\
\text { MANAGEMENT } \\
\text { A.D. BEOGRAD }\end{array}$ & $\begin{array}{l}19.10 .2 \\
017 .\end{array}$ & $\begin{array}{c}\text { VOJVOĐANSK } \\
\text { A BANKA A.D. } \\
\text { NOVI SAD }\end{array}$ \\
\hline $\begin{array}{l}\text { ILIRIKA } \\
\text { DYNAMIC }\end{array}$ & отворен & $\begin{array}{c}\text { фонд раста } \\
\text { вредности } \\
\text { имовине }\end{array}$ & $\begin{array}{l}\text { ILIRIKA DZU A.D. } \\
\text { BEOGRAD }\end{array}$ & $\begin{array}{l}29.01 .2 \\
009 .\end{array}$ & $\begin{array}{c}\text { KOMERCIJALN } \\
\text { A BANKA A.D. } \\
\text { BEOGRAD }\end{array}$ \\
\hline TRIUMPH & отворен & $\begin{array}{c}\text { фонд раста } \\
\text { вредности } \\
\text { имовине } \\
\end{array}$ & $\begin{array}{l}\text { ILIRIKA DZU A.D. } \\
\text { BEOGRAD }\end{array}$ & $\begin{array}{l}21.02 .2 \\
008 .\end{array}$ & $\begin{array}{c}\text { VOJVOĐANSK } \\
\text { A BANKA A.D. } \\
\text { NOVI SAD }\end{array}$ \\
\hline $\begin{array}{c}\text { WVP } \\
\text { DYNAMIC }\end{array}$ & отворен & $\begin{array}{c}\text { фонд раста } \\
\text { вредности } \\
\text { имовине }\end{array}$ & $\begin{array}{l}\text { WVP FUND } \\
\text { MANAGEMENT } \\
\text { A.D. BEOGRAD }\end{array}$ & $\begin{array}{l}19.10 .2 \\
017 .\end{array}$ & $\begin{array}{c}\text { VOJVOĐANSK } \\
\text { A BANKA A.D. } \\
\text { NOVI SAD }\end{array}$ \\
\hline $\begin{array}{c}\text { WVP } \\
\text { PREMIUM }\end{array}$ & отворен & $\begin{array}{c}\text { фонд раста } \\
\text { вредности } \\
\text { имовине }\end{array}$ & $\begin{array}{l}\text { WVP FUND } \\
\text { MANAGEMENT } \\
\text { A.D. BEOGRAD }\end{array}$ & $\begin{array}{c}19.10 .2 \\
017 .\end{array}$ & $\begin{array}{c}\text { VOJVOĐANSK } \\
\text { A BANKA A.D. } \\
\text { NOVI SAD }\end{array}$ \\
\hline
\end{tabular}

Просечна стопа раста вредности инвестиционих јединица била 7,53\% у предходних 5 година, односно 
чак 4\% у првих 6 месеци 2019. године. Ако при томе узмемо у обзир да и просечна вредност имовине ових фондова је порасла за невероватних $378,49 \%$ тј чак

47,06\% у првих шест месеци 2019. године. Све ово јасно указује да је инвестирање у инвестиционе фондове у Србији кренуло изузетно брзо да се развија и да је један од показатеља раста улагања и укључивања Интеза банке преко свог друштва за управљање на тржиште инвестиционих фондова. Фондови који се базирају на депозитима и државним хартијама од вредностима Републике Србије, они који су највише донели, али без обзира, треба узети у разматрање и улагање у фондове на дуже периоде. Фондови засновани на домаћим акцијама и депозитима у динарима (нпр Kombank novčani fond) су остварили добре приносе приносе, али то је више везано за релативну стабилност нашег тржишта и валуте динара у претходном периоду.

Табела 2: Упоредни приказ трошкова и накнада инвестиционих фондова и друштава за управљање инвестиционим фондовима у Републици Србији

\begin{tabular}{|c|c|c|c|}
\hline $\begin{array}{l}\text { Друштво за } \\
\text { управљање }\end{array}$ & Улазна накнада & $\begin{array}{l}\text { Излазна } \\
\text { накнада }\end{array}$ & $\begin{array}{l}\text { Ушравльач } \\
\text { ка накнад } \\
\text { (годипььа }\end{array}$ \\
\hline $\begin{array}{c}\text { ILIRIKA DZU A.D. } \\
\text { BEOGRAD } \\
\end{array}$ & $0,00-1,00 \%$ & $\begin{array}{l}0,00- \\
1,00 \% \\
\end{array}$ & $1.5 \%$ \\
\hline $\begin{array}{c}\text { ILIRIKA DZU A.D. } \\
\text { BEOGRAD }\end{array}$ & $0,00-1,00 \%$ & $\begin{array}{l}0,00- \\
1,00 \%\end{array}$ & $0.3 \%$ \\
\hline $\begin{array}{c}\text { ILIRIKA DZU A.D. } \\
\text { BEOGRAD } \\
\end{array}$ & $0,00-1,00 \%$ & 0 & $1 \%$ \\
\hline $\begin{array}{c}\text { ILIRIKA DZU A.D. } \\
\text { BEOGRAD }\end{array}$ & $2,5 \%-4,5 \%$ & 0 & $3.65 \%$ \\
\hline $\begin{array}{c}\text { ILIRIKA DZU A.D. } \\
\text { BEOGRAD }\end{array}$ & 0 & $\begin{array}{l}0,00- \\
1,00 \%\end{array}$ & $2.50 \%$ \\
\hline $\begin{array}{c}\text { INTESA INVEST } \\
\text { AD BEOGRAD }\end{array}$ & 0 & $\begin{array}{l}0,00- \\
1,00 \%\end{array}$ & $1 \%$ \\
\hline $\begin{array}{c}\text { INTESA INVEST } \\
\text { AD BEOGRAD }\end{array}$ & 0 & 0 & $0.80 \%$ \\
\hline $\begin{array}{c}\text { KOMBANK } \\
\text { INVEST A.D. } \\
\text { BEOGRAD } \\
\end{array}$ & $0.0 \%-2.5 \%$ & $\begin{array}{l}0.0 \%- \\
1.0 \%\end{array}$ & $3.00 \%$ \\
\hline $\begin{array}{l}\text { KOMBANK } \\
\text { INVEST A.D. } \\
\text { BEOGRAD } \\
\end{array}$ & 0 & 0 & $0.50 \%$ \\
\hline $\begin{array}{l}\text { KOMBANK } \\
\text { INVEST A.D. } \\
\text { BEOGRAD }\end{array}$ & 0 & 0 & $1 \%$ \\
\hline $\begin{array}{l}\text { RAIFFEISEN } \\
\text { INVEST A.D. } \\
\text { BEOGRAD } \\
\end{array}$ & $0-1 \%$ & $0-1 \%$ & $1 \%$ \\
\hline $\begin{array}{l}\text { RAIFFEISEN } \\
\text { INVEST A.D. } \\
\text { BEOGRAD } \\
\end{array}$ & 0 & $0-3 \%$ & $2 \%$ \\
\hline $\begin{array}{l}\text { RAIFFEISEN } \\
\text { INVEST A.D. } \\
\text { BEOGRAD }\end{array}$ & 0 & 0 & $1 \%$ \\
\hline $\begin{array}{c}\text { WVP FUND } \\
\text { MANAGEMENT } \\
\text { A.D. BEOGRAD }\end{array}$ & 0 & 0 & $1 \%$ \\
\hline $\begin{array}{l}\text { WVP FUND } \\
\text { MANAGEMENT } \\
\text { A.D. BEOGRAD }\end{array}$ & $0.7-3.5 \%$ & 0 & $1.50 \%$ \\
\hline $\begin{array}{c}\text { WVP FUND } \\
\text { MANAGEMENT } \\
\text { A.D. BEOGRAD }\end{array}$ & $1-5 \%$ & 0 & $2 \%$ \\
\hline $\begin{array}{l}\text { WVP FUND } \\
\text { MANAGEMENT } \\
\text { A.D. BEOGRAD }\end{array}$ & $1-5 \%$ & 0 & $2 \%$ \\
\hline
\end{tabular}

\section{5. ЗАКЉУЧАК}

Гледајући целокупно тржиште инвестиционих фондова, без сумње се може закључити да је оно у узлазној путањи, али мали број регистрованих инвестиционих фондова указује ипак на одређену уздржаност инвеститора за отварање нових друштава за управљање и нових инвестиционих фондова. Иако нису загарантовани приноси, ако узмемо у обзир да камате на штедњу у банкама иду силазном путањом, можемо са сигурношћу очекивати даљи раст поверења у овај вид улагања пре свега и због брзине доступности средстава поготово код „новчаних“ фондова који имају и ниже накнаде и трошкове.

Такође је битно напоменути, да тренутно осигуравајуће куће преко програма животног осигурања, немају у понуди програме који су везани за инвестиционе фондове са изузетком WIENER STADTICHE која има програм Mој активни капитал који је везан претежно за WVP фондове који су још увек релативно млади. Ипак, треба имати у виду да и тржиште осигурања још увек није довољно развијено у смислу процента животно осигураних лица у Републици Србији, те самим тим, растом ове гране, можемо очекивати и пораст улагања и отварање нових друштава за управљање и нових инвестиционих фондова, јер ће се у неком моменту вероватно и осигуравајуће куће укључити у ово тржиште, као што је случај и у свету.

\section{ЛИТЕРАТУРА}

[1] Анђелић Г.: „Инвестирање”, Монографија, Факултет техничких наука, Нови Сад, 2006.

[2] Анђелић Г., Ђаковић, В.: „Основе инвестиционог менаџмента", Факултет техничких наука, Нови Сад, 2010.

[3] Ханић, Х.: „О приватизацији банака у Србији”, Београд, 2005.

[4] Марић, Б.: „Управљање инвестиуцијама”, Факултет техничких наука, Нови Сад, 2010.

[5] Неранџић Б., Перовић В.: Управљачко рачуноводство, Факултет техничких наука, 2013.

[6] Перовић В., Неранџић Б.: Пословне финансије, Факултет техничких наука, 2010.

[7] Ристић Ж .: „Тржиште капитала - теорија и пракса“" Цигоја, 1990. година, Београд

[8] Шошкић, Д., Живковић, Б.: „Финансијска тржишта и институције”, Центар за издавачку делатност економског факултета у Београду, Београд, 2006.

\section{Кратка биографија:}

Ивана Сабо, рођена 12.07.1985. у Новом Саду, одбранила је мастер рад из области инжењерског менаџмента, 2019. године. 